
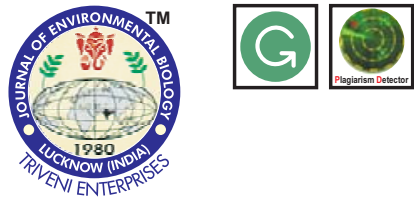

\title{
Virulence and genetic diversity of Sclerotium rolfsii Sacc., infecting groundnut using nuclear (RAPD \& ISSR) markers
}

Authors Info

M. Daniel Jebaraj*,

K. Eraivan Arutkani Aiyanathan and S. Nakkeeran

Department of Plant Pathology, Centre for Plant Protection Studies, Tamil Nadu Agricultural University, Coimbatore-641 003, India

${ }^{*}$ Corresponding Author Email : daniel.jebaraj2011@gmail.com

Key words

Genetic diversity,

Groundnut, ISSR,

RAPD, Sclerotium rolfsii,

Virulence

Publication Info

Paper received : 24.02 .2016

Revised received: 14.06 .2016

Re-revised received : 10.10 .2016

Accepted : 24.10 .2016

\section{Abstract}

Aim : Assess the virulence and genetic diversity of Sclerotium rolfsii isolates causing stem rot disease in groundnut collected from different geographical regions of Tamil Nadu using nuclear markers viz., RAPD and ISSR.

Methodology : Survey was conducted in major groundnut growing areas of Tamil Nadu and twenty two cultures of S.rolfsii ( 18 from groundnut and 4 from other crops) were collected and isolated. Subsequently the virulence of S.rolfsii was tested. Genomic DNA was extracted from S.rolfsii isolates and assessed their genetic diversity using nuclear markers viz., RAPD and ISSR.

Results : Among the 22 isolates of $S$. rolfsii, the isolate from Udumalpet (SrUDM) showed higher per cent disease incidence (80.95\%) followed by K.G. Savadi (SrKGS) and Tindivanam (SrTVM) isolates (61.90\%), whereas the isolate from Madurai recorded lower per cent disease incidence (33.33\%). ITS region of rDNA amplification with specific ITS-1 and ITS-4 universal primers produced the amplicon of approximately 650 to $700 \mathrm{bp}$ and confirmed that all the 22 isolates belongs to the genus Sclerotium. Ten different oligonucleotide primers of RAPD and ISSR were used to assess the genetic diversity among 22 isolates of $S$. rolfsii. The dendrogram results indicated that all the $S$. rolfsii isolates from Tamil Nadu formed two distinct clusters. A total of 121 and 123 reproducible and scorable polymorphic bands recorded and ranging from 100 to $2500 \mathrm{bp}$ and 250 to 2000 bp were generated with ten numbers of RAPD and ISSR primers, respectively. The ISSR marker recorded an average PIC of 0.87 as against 0.86 of RAPD and the effective multiplication ratio was also superior in ISSR (12.21) compared to RAPD (12.00).

Interpretation: The result of the present study indicated that ISSR markers were suited well for genetic diversity studies of $S$. rolfsii than RAPD and no correlation was observed between the virulence and genetic diversity of various $S$. rolfsii isolates using nuclear markers. 


\section{Introduction}

Groundnut (Arachis hypogaea, L.) is considered as a major oilseed crop of India and positioned first place among the oil seeds. It is cultivated in an area of 52.50 lakhs ha with an annual production and productivity of 94.72 lakh tonnes and $1804 \mathrm{~kg} \mathrm{ha}^{-1}$, respectively in India. Among the top ten major groundnut growing states of India, Tamil Nadu accounts an area of 3.42 lakh ha, with an annual production of 9.62 lakh tonnes and productivity of 2813 $\mathrm{kg} \mathrm{ha}^{-1}$ (Anonymous, 2014). Despite the adaption of crop to all seasons, the production of groundnut is being challenged by the panorama of diseases viz., leaf spot, collar rot, stem rot, bud necrosis and other diseases. Among the major fungal diseases, the stem rot disease caused by Sclerotium rolfsii Sacc., is a major constraint for the production of groundnut (Johnson et al., 2008) and its attributes significant amount of yield loss in groundnut. Rodriguez et al. (1975) reported that normally groundnut stem rot causes pod yield loss of 10-25\% under regular condition, whereas in severe condition it accounts around $80 \%$ of yield loss. S. rolfsii is a soil borne plant pathogen causing diseases on wide range of economically important agricultural and horticultural crops, including groundnut, cotton, soybean, sunflower, wheat, legumes, tomato, chilli, potato, crucifers, cucurbits, onion and others (Hossain, 2000).

A wide range of host, profuse mycelial growth, ability to produce persistent sclerotia (Asghari and Mayee, 1991; Kokub et al., 2007) and typical damaging symptom of yellowing and wilting of branches contribute to the greater economic loss. Integrated management of $S$. rolfsii is considered as the most effective method for their management. In order to implement the effective integrated management strategy against $S$. rolfsii, the informations on current status and genetic variability is vital. Till date, limited work has been done on genetic variability of $S$. rolfsii isolates (Prasad et al., 2010). Molecular markers play a major role in analyzing the genetic variation of fungal pathogens (Punja and Sun, 2001; Adhipathi et al., 2013). Among the molecular markers, the nuclear DNA markers viz., RAPD and ISSR are the markers of choice for genetic variation studies because of their high level of polymorphism (Moulin et al., 2012). Hence, the present study focused on genetic variation of $S$. rolfsii isolates of groundnut collected from different geographical regions of Tamil Nadu using RAPD and ISSR markers.

\section{Materials and Methods}

Collection of samples : Survey and collection of stem rot infected groundnut samples were done in major groundnut growing areas of Tamil Nadu (Table 1). The stem rot infected groundnut, plants were pulled out with intact roots showing the presence of white mycelial mat with small round brown sclerotia and gently tapped to remove the soil adhering on the root region. The samples were bagged with butter paper and then placed in polythene cover. The field collected samples were brought to the laboratory, Department of Plant Pathology, Tamil Nadu Agricultural University, Coimbatore for further isolation of $S$. rolfsii.

Table 1 : List of S. rolfsii isolates collected from different groundnut growing regions of Tamil Nadu

\begin{tabular}{llll}
\hline Isolates & Source & Location & District \\
\hline SrPLC & Groundnut & Pollachi & Coimbatore \\
SrKGS & Groundnut & K.G.Savadi & Coimbatore \\
SrCBE & Groundnut & Coimbatore & Coimbatore \\
SrKNK & Groundnut & Kinathukadavu & Coimbatore \\
SrDGL & Groundnut & Dindigul & Dindigul \\
SrBTG & Groundnut & Batlagundu & Dindigul \\
SrUSP & Groundnut & Usilampatti & Madurai \\
SrMDU & Groundnut & Madurai & Madurai \\
SrTHN & Groundnut & Theni & Theni \\
SrANP & Groundnut & Andipatti & Theni \\
SrVLR & Groundnut & Vellore & Vellore \\
SrVAL & Groundnut & Vallanadu & Tuticorin \\
SrTVM & Groundnut & Tindivanam & Villupuram \\
SrMDT & Groundnut & Madurantakam & Kanchipuram \\
SrTRM & Groundnut & Thiruvannamalai & Thiruvannamalai \\
SrUDM & Groundnut & Udumalpet & Tiruppur \\
SrERP & Groundnut & Erisanampatti & Tiruppur \\
SrKAN & Groundnut & Kaniyur & Tiruppur \\
SrBLG & Blackgram & Madurai & Madurai \\
SrSUN & Sunflower & Coimbatore & Coimbatore \\
SrJAS & Jasmine & Nilakottai & Dindigul \\
SrTOM & Tomato & Kinathukadavu & Coimbatore \\
\hline
\end{tabular}


Isolation of S. rolfsii from infected groundnut : The S. rolfsii was isolated from the diseased groundnut plants by tissue segment method (Rangaswami, 1996). The infected stem portion of groundnut, collected from different area, were cut into small pieces $(1.0 \mathrm{~cm}$ size) using sterilized scalpel blade and surface sterilized with $0.1 \%$ mercuric chloride for one minute. Subsequently the pieces were washed in sterile distilled water thrice and then placed in a Petri plate at equidistance onto previously poured and solidified Potato Dextrose Agar (PDA) medium. In order to prevent the contamination of bacteria, the bacterial antibiotic (Streptomycin sulphate) was added at 1000 ppm into the sterile PDA medium at $60^{\circ} \mathrm{C}$. These plates were incubated at $28 \pm 2{ }^{\circ} \mathrm{C}$ room temperature and $65 \pm 5 \%$ relative humidity for five days and observed for fungal growth.

The pathogen was identified based on their cultural and morphological characters (Punja, 1985). A loop full of fungal culture grown on PDA plates were taken on a glass slide and observed with image analyzer (LABOMED iVu5100, Labo America Inc, USA) under light microscope. After confirming the sclerotia, the cultures were purified and maintained for further studies (Ricker and Ricker, 1936). The pathogen from other hosts viz., tomato, jasmine, sunflower and black gram were also isolated, purified and maintained to compare the genetic variability of $S$. rolfsii isolates with groundnut isolates.

Virulence of isolates of the pathogen : A pot culture experiment was conducted to test the virulence of different $S$. rolfsii isolates collected from various groundnut growing areas of Tamil Nadu. Mass multiplication of $S$. rolfsii was followed in sand maize medium. Two hundred grams of sand maize mixture was taken in polybags and mixed with 30 per cent of distilled water and they were sterilized at $15 \mathrm{lb}$ pressure for $20 \mathrm{~min}$. The pure culture of each $S$. rolfsii isolate was inoculated to the polybags under aseptic conditions and incubated at $28 \pm 2^{\circ} \mathrm{C}$ for 20 days. The polybags were shaken periodically to get uniform growth of the pathogen. Subsequently the mass cultures thus obtained were used for further studies.

Assessing the virulence of $S$. rolfsii isolates by pot culture method: The potting mixture was prepared by mixing clay loam soil, sand and farm yard manure in the ratio of 1:1:1 ratio. Potting mixture was sterilized in an autoclave at $1.4 \mathrm{~kg} \mathrm{~cm}^{-2}$ pressure for 2 $\mathrm{hr}$ on two successive days. Earthen pots with uniform size of $30 \mathrm{~cm}$ diameter were used for filling the soil and mass cultured inoculum. The inoculum of each isolate of $S$. rolfsiigrown on sand maize medium (20 days old) was mixed thoroughly at $5 \%$ (w/w basis) level, and applied on top two centimeter of the soil. Then groundnut seeds were sown in the inoculated pots. Each isolate was considered as treatment and three replications were maintained for each treatment. The seeds sown in pots without inoculums served as control. Soil moisture was maintained at moisture holding capacity of soil by adding sterilized water on weight basis throughout the period. Seed infection started within three days of sowing. After 20 days of sowing, plants showing typical seedling rot symptoms were observed. Reisolation was made from the affected portion of the plant tissue and compared with that of original isolate for conformity. Per cent disease incidence (Kokalis-Burelle et al., 1992) was measured.

Molecular confirmation of $S$. rolfsii isolates with ITS primers : For molecular confirmation, the genomic DNA from $S$. rolfsii was obtained using CTAB method (Zolan and Pukkila, 1996). The Internal Transcribed Spacer (ITS) of rDNA was used to amplify different S.rolfsii isolates using universal primers ITS-1 (5' TCCGTAGGTGGACCTGCGG - 3') as forward primer and ITS-4 (5'-TCCTCCGCTTATTGATATGC- $3^{\prime}$ ) as reverse primer (White et al., 1990). PCR amplification was carried out as $25 \mu$ reaction mixture containing $2.5 \mu$ lof $10 \mathrm{x}$ Taq buffer, $0.5 \mu \mathrm{l}$ of $25 \mathrm{mM} \mathrm{MgCl} 2$, $2.0 \mu$ of ITS-1 forward primer ( 0.6 picomolar $\left.\mu I^{-1}\right), 2.0 \mu$ l of ITS-4 reverse primer $\left(0.6\right.$ picomolar $\left.\mu l^{-1}\right), 0.5 \mu$ of $100 \mathrm{mM} \mathrm{dNTP}$ mix,

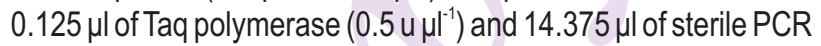
water (Genei, Bangalore) and $3 \mu \mathrm{l}(50-60 \mathrm{ng}$ ) of DNA sample. Reactions were performed using a Eppendorf PCR master cycler. PCR cycling conditions consist of 35 cycles, of which denaturation at $94^{\circ} \mathrm{C}$ for $1 \mathrm{~min}$, annealing at $56^{\circ} \mathrm{C}$ for $1 \mathrm{~min}$ and extension at $72^{\circ} \mathrm{C}$ for $1.5 \mathrm{~min}$ with initial denaturation at $94^{\circ} \mathrm{C}$ for 4 min before cycling and final extension at $72^{\circ} \mathrm{C}$ for 6 min after cycling. The size of the PCR product was estimated by comparison with known DNA marker of 100 bp DNA ladder. The banding profiles of ITS-PCR products were documented by gel documentation system .

Genetic diversity analysis of $S$. rolfsii isolates using RAPD Primers : Total volume of $20 \mu \mathrm{l}$ PCR reaction mixture containing DNA template 25ng, 10x Taq buffer, $2.5 \mathrm{mM}$ each of dNTP mixture, $2.5 \mathrm{mM}$ of $\mathrm{MgCl}_{2}, 30$ picomole of random primer, and 3 units of Taq DNA polymerase (Genei, Bangalore). PCR amplification was performed in a thermocycler using the following conditions: initial denaturation at $94^{\circ} \mathrm{C}$ for $5 \mathrm{~min}, 30$ cycles of denaturation at $94^{\circ} \mathrm{C}$ for $1 \mathrm{~min}$, annealing at $36^{\circ} \mathrm{C}$ for $1 \mathrm{~min}$, extension at $72^{\circ} \mathrm{C}$ for $2 \mathrm{~min}$, and a final elongation at $72^{\circ} \mathrm{C}$ for 5 min (Gaitan et al., 2002). A set of 10 random primers used in this study; OPA-01 (CAGGCCCTTC), OPA-02 (TGCCGAGCTG), OPA-03 (AGTCAGCCAC), OPA-04 (AATCGGGCTG), OPA-05 (AGGGGTCTTG), OPA-06 (GGTCCCTGAC), OPA-07 (GAAACGGGTG), OPA-08 (GTGACGTAGG), OPA-09 (GGGTAACGCC) and OPA-10 (GTGATCGCAG). The amplified PCR products were screened on 1.5 per cent agarose gel.

RAPD scoring and data analysis : The banding patterns obtained from RAPD primers were analyzed based on the presence and absence of each band, coded as 1 and 0 respectively. The scores were used to create a data matrix to analyze genetic relationship using the NTSYS-pc program version 2.02 (Exeter Software, New York, USA) described by Rohlf (1993). A dendrogram was constructed based on Jaccard's similarity coefficient (Jaccard, 1908) using the marker data from 
S. rolfsii isolates with unweighted pair-group method on arithmetic average (UPGMA) cluster analysis to group the isolates based on their similarities. The relationships among the isolates were examined and presented as dendrogram by using UPGMA.

PCR details for amplification of ISSR primers : A set of ten ISSR primers were used for assessing the genetic diversity of $S$. rolfsii. The list of primers and PCR conditions used were given in Table 2. For ISSR, the amplifications were run in a final volume of $20 \mu$ cocktail mixture including, Tris- $\mathrm{HCl}\left(10 \mathrm{mmol} \mathrm{I}^{-1}\right), \mathrm{pH} 8.3, \mathrm{KCl}$ (50 mmol l-1), MgCl2 (2.4 mmol I'), dNTP (100 $\mu \mathrm{mol} \mathrm{I}^{-1}$ of each), Oligonucleotide primers $\left(0.4 \mu \mathrm{mol} \mathrm{I}^{-1}\right)$, Genomic DNA (50 - 100 $\mathrm{ng}$ ), and Taq DNA polymerase ( 0.75 units). Agarose gel electrophoresis and data analysis was done as in RAPD.

The efficacy of molecular markers viz., RAPD and ISSR for assessing the genetic diversity of $S$. rolfsii isolates : Two marker systems viz., RAPD and ISSR were compared for their efficiency in assessing the genetic diversity of $S$. rolfsii isolates. The parameters viz., total number of bands, the number of monomorphic and polymorphic bands, bands per primer, per cent polymorphism and monomorphism were documented. In addition, Polymorphic Information Content (PIC) was calculated by the formula developed by Anderson et al. (1993).

Marker Index (MI) was determined as the product of PIC and the number of polymorphic bands per assay unit and $E M R(E)$ is the product of the fraction of polymorphic loci and the number of polymorphic loci for an individual assay (Powell et al., 1996).

\section{Results and Discussion}

Stem rot disease caused by $S$. rolfsii isolates ranged from 33.33 to $80.95 \%$ disease incidence. Among the twenty two isolates tested in the present study, the $S$. rolfsii isolate collected from Udumalpet (SrUDM) showed higher per cent disease incidence $(80.95 \%)$, followed by K.G. Savadi (SrKGS) and Tindivanam (SrTVM) isolates $(61.90 \%)$. However, the isolate collected from Madurai recorded low per cent disease incidence (33.33\%). The S. rolfsii isolated on groundnut samples collected from Kinathukadavu (SrKNK), Andipatti (SrANP), Maduranthagam (SrMDT), Tiruvannamalai (SrTRM), Erisanampatti (SrERP) and the pathogen isolated on blakgram (SrBLG), jasmine (SrJAS) and tomato (SrTOM) from Madurai, Nilakottai and Kinathukadavu, respectively showed 50 to 60 per cent, whereas the remaining samples from Pollachi (SrPLC), Coimbatore (SrCBE), Dindigul (SrDGL), Butlagundu (SrBTG), Usilampatti (SrUSP), Theni (SrTHN), Vellore (SrVLR), Vallanad (SrVAL) and Kaniyur (SrKAN) recorded 30 to $40 \%$ disease incidence (Table 3).

The field collected $S$. rolfsii isolates were amplified with ITS universal primers viz., ITS-1 (forward) and ITS-4 (reverse)

Table 2 : ISSR primers and PCR conditions used in the study

\begin{tabular}{|c|c|c|c|c|}
\hline Nucleotide sequence 5' to 3' & PCR conditions & Duration & No of Cycles & Reference \\
\hline $\begin{array}{l}\text { 1. }(\mathrm{CAG})_{5} \\
\text { 2. }(\mathrm{GTG})_{5} \\
\text { 3. }(\mathrm{AGG})_{5}\end{array}$ & $\begin{array}{l}\text { Initial denaturation } \\
\text { Denaturation } \\
\text { Annealing } \\
\text { Extension } \\
\text { Final extension }\end{array}$ & $\begin{array}{l}95^{\circ} \mathrm{C} ; 5 \mathrm{~min} . \\
95^{\circ} \mathrm{C} ; 30 \mathrm{sec} \\
60^{\circ} \mathrm{C} ; 30 \mathrm{sec} \\
72^{\circ} \mathrm{C} ; 1.5 \mathrm{~min} . \\
72^{\circ} \mathrm{C} ; 10 \mathrm{~min} .\end{array}$ & $\begin{array}{l}1 \\
30\end{array}$ & Gupta and Filner, 1991 \\
\hline 4. $(\mathrm{GACA})_{4}$ & $\begin{array}{l}\text { Initial denaturation } \\
\text { Denaturation } \\
\text { Annealing } \\
\text { Extension } \\
\text { Final extension }\end{array}$ & $\begin{array}{l}95^{\circ} \mathrm{C} ; 5 \mathrm{~min} . \\
95^{\circ} \mathrm{C} ; 30 \mathrm{sec} \\
48^{\circ} \mathrm{C} ; 30 \mathrm{sec} \\
72^{\circ} \mathrm{C} ; 1.5 \mathrm{~min} . \\
72^{\circ} \mathrm{C} ; 10 \mathrm{~min} .\end{array}$ & $\begin{array}{l}1 \\
30\end{array}$ & Weising et al., 1989 \\
\hline 5. $(\mathrm{TCC})_{5}$ & $\begin{array}{l}\text { Initial denaturation } \\
\text { Denaturation } \\
\text { Annealing } \\
\text { Extension } \\
\text { Final extension }\end{array}$ & $\begin{array}{l}95^{\circ} \mathrm{C} ; 5 \mathrm{~min} . \\
94^{\circ} \mathrm{C} ; 1 \mathrm{~min} . \\
46^{\circ} \mathrm{C} ; 1 \mathrm{~min} . \\
72^{\circ} \mathrm{C} ; 1.5 \mathrm{~min} . \\
72^{\circ} \mathrm{C} ; 10 \mathrm{~min} .\end{array}$ & $\begin{array}{l}1 \\
30\end{array}$ & Gupta and Filner, 1991 \\
\hline 6. $(\mathrm{CAC})_{5}$ & $\begin{array}{l}\text { Initial denaturation } \\
\text { Denaturation } \\
\text { Annealing } \\
\text { Extension } \\
\text { Final extension }\end{array}$ & $\begin{array}{l}95^{\circ} \mathrm{C} ; 5 \mathrm{~min} . \\
94^{\circ} \mathrm{C} ; 1 \mathrm{~min} . \\
51^{\circ} \mathrm{C} ; 1 \mathrm{~min} . \\
72^{\circ} \mathrm{C} ; 2 \mathrm{~min} . \\
72^{\circ} \mathrm{C} ; 10 \mathrm{~min} .\end{array}$ & $\begin{array}{l}1 \\
40\end{array}$ & Gupta et al., 1994 \\
\hline $\begin{array}{l}\text { 7. }(A G)_{8} T \\
\text { 8. }(A G)_{8} C \\
\text { 9. }(G A)_{8} T \\
\text { 10. }(T G)_{8} A\end{array}$ & $\begin{array}{l}\text { Initial denaturation } \\
\text { Denaturation } \\
\text { Annealing } \\
\text { Extension } \\
\text { Final extension }\end{array}$ & $\begin{array}{l}94^{\circ} \mathrm{C} ; 2 \mathrm{~min} . \\
94^{\circ} \mathrm{C} ; 1 \mathrm{~min} . \\
52^{\circ} \mathrm{C} ; 1 \mathrm{~min} . \\
72^{\circ} \mathrm{C} ; 1.5 \mathrm{~min} . \\
72^{\circ} \mathrm{C} ; 6 \mathrm{~min} .\end{array}$ & $\begin{array}{l}1 \\
35\end{array}$ & Ratanacherdchai et al., 2007 \\
\hline
\end{tabular}


Table 3: Virulence of S. rolfsii isolates in groundnut

\begin{tabular}{ll}
\hline S. rolfsii lsolates & Disease Incidence $(\%)$ \\
\hline SrPLC & $47.62(43.63)^{\mathrm{e}}$ \\
SrKGS & $61.90(51.89)^{\mathrm{b}}$ \\
SrCBE & $42.86(40.89)^{\mathrm{f}}$ \\
SrKNK & $52.38(46.36)^{\mathrm{d}}$ \\
SrDGL & $42.86(40.89)^{\mathrm{f}}$ \\
SrBTG & $38.10(38.11)^{\mathrm{g}}$ \\
SrUSP & $38.10(38.11)^{\mathrm{g}}$ \\
SrMDU & $33.33(35.26)^{\mathrm{h}}$ \\
SrTHN & $47.62(43.63)^{\mathrm{e}}$ \\
SrANP & $52.38(46.36)^{\mathrm{d}}$ \\
SrVLR & $42.86(40.89)^{\mathrm{f}}$ \\
SrVAL & $38.10(38.11)^{\mathrm{g}}$ \\
SrTVM & $61.90(51.89)^{\mathrm{b}}$ \\
SrMDT & $57.14(49.11)^{\mathrm{c}}$ \\
SrTRM & $52.38(46.36)^{\mathrm{d}}$ \\
SrUDM & $80.95(64.20)^{\mathrm{a}}$ \\
SrERP & $52.38(46.36)^{\mathrm{d}}$ \\
SrKAN & $47.62(43.63)^{\mathrm{e}}$ \\
SrBLG & $52.38(46.36)^{\mathrm{d}}$ \\
SrSUN & $47.62(43.63)^{\mathrm{e}}$ \\
SrJAS & $57.14(49.11)^{\mathrm{c}}$ \\
SrTOM & $52.38(46.36)^{\mathrm{d}}$ \\
Control & 0 \\
\hline
\end{tabular}

Values are mean of three replicates; Figures in parentheses represent arcsine transformation; Means in a column followed by same superscript letters are not significantly different according to DMRT at $P \leq 0.05$

and the amplicon size recorded were 650-700bp (Fig. 1). It showed that the isolates collected from different locations confirmed as the genus Sclerotium. This is in confirmation with the earlier report of Harlton et al. (1995) who screened worldwide collection of S. rolfsii revealing variation in ITS regions of 12 subgroups of $S$. rolfsii. Similar findings were also observed by Almeida et al. (2001) who reported genetic confirmation of $S$. rolfsii with ITS primers. In addition, the present study is in concordance with Prasad et al. (2010) who studied the molecular variability of $S$. rolfsii isolates using ITS-PCR primers and found molecular confirmation of $S$. rolfsii isolates and significant genetic variations among the isolates. The results of the present study also reported that the ITS - PCR was an effective tool for the identification of fungal pathogens, including genus Sclerotium.

Genetic diversity of fungal pathogens is essential for the assessment of characteristics and diversity of fungal pathogens and it would be helpful for the development of effective integrated disease management strategy. Nuclear markers play a major role in genetic study of living organisms particularly the efficiency of RAPD, as a arbitrary DNA marker has been extensively reported as efficient marker for genetic diversity studies. The researchers from phytopathaology enunciated the potential of RAPD markers for assessing the diversity of fungal and other pathogens (Thilagavathi et al., 2013; Kumar et al.,2014; Mallaiah and Muthamilan, 2015). Thus, the present study tested the field collected $S$. rolfsii isolates with ten RAPD primers viz., OPA-01, OPA-02, OPA-03, OPA-04, OPA-05, OPA-06, OPA-07, OPA-08, OPA-09 and OPA-10. All the primers were amplified with S. rolfsii isolates showed polymorphic and distinguishable banding pattern. A total of 121 reproducible and scorable polymorphic bands with 100 to 2500 bp were generated among the 22 isolates. Among the primers, the primer OPA-09 yielded maximum of 17 total bands, followed by OPA-05 that showed 15 bands. In polymorphism, most of the primers showed cent percent polymorphism, except for the primer OPA-03 and OPA-09 (Table 4; Fig. 2).

Relationship among the isolates was evaluated by cluster analysis of data based on similarity matrix. The dendrogram was generated by using UPGMA package based on Ward's Squared Equalidean Distance method (Fig. 3). All the 22 isolates of $S$. rolfsii were grouped into two main clusters. Cluster I had 20

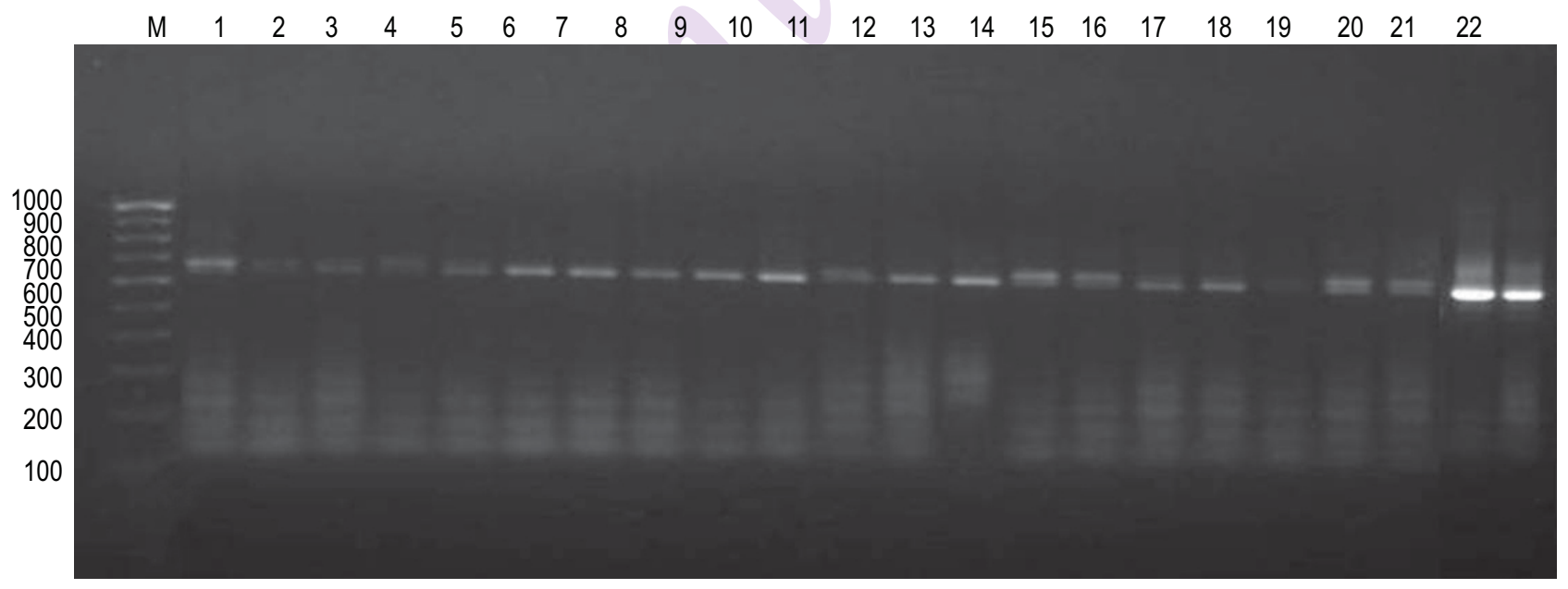

Fig. 1 : Molecular characterization of S.rolfsii isolates by ITS-PCR. Isolates numbers are shown as 1 to 22 . M-100bp molecular marker 


\section{$\begin{array}{lllllllllllllllllllllllll}M & 1 & 2 & 3 & 4 & 5 & 6 & 7 & 8 & 9 & 10 & 11 & 12 & 13 & 14 & 15 & 16 & 17 & 18 & 19 & 20 & 21 & 22 & 23 & 24\end{array}$}

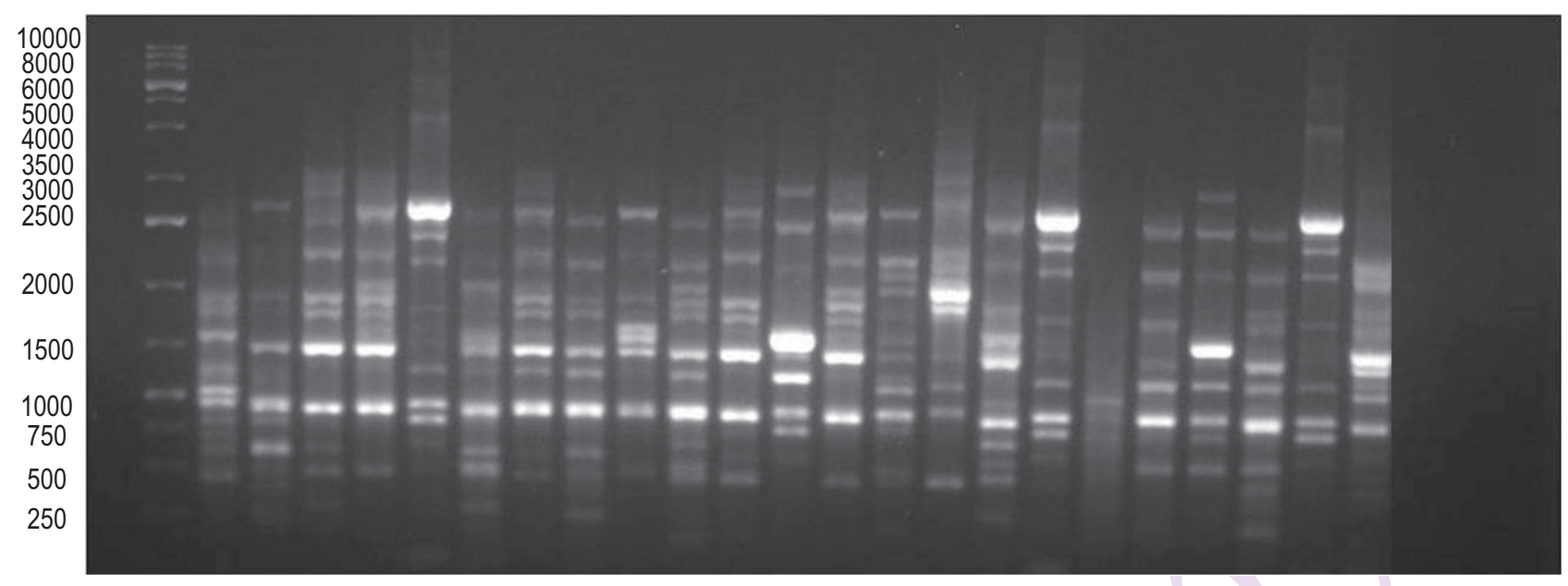

Fig. 2 : RAPD of S. rolfsii isolates using OPA-03 primer. Isolates numbers are shown as 1 to 22.23 - Positive control. 24 - Negative control. M-1Kb molecular marker.

Table 4 : Polymorphism, PIC and EMR of S. rolfsii isolates revealed by RAPD

\begin{tabular}{llllllll}
\hline Primers & Total of bands & $\begin{array}{l}\text { No. of } \\
\text { Polymorphic } \\
\text { bands }\end{array}$ & $\begin{array}{l}\text { No.of } \\
\text { Monomorphic } \\
\text { bands }\end{array}$ & $\begin{array}{l}\text { Percent } \\
\text { Polymorphic } \\
\text { bands }\end{array}$ & $\begin{array}{l}\text { Percent } \\
\text { Monomorphic } \\
\text { bands }\end{array}$ & PIC Value & EMR \\
\hline OPA1 & 11 & 11 & 0 & 100 & 0.00 & 0.902 & 11.00 \\
OPA2 & 09 & 09 & 0 & 100 & 0.00 & 0.836 & 09.00 \\
OPA3 & 13 & 12 & 1 & 99.41 & 0.59 & 0.912 & 12.85 \\
OPA4 & 10 & 10 & 0 & 100 & 0.00 & 0.845 & 10.00 \\
OPA5 & 15 & 15 & 0 & 100 & 0.00 & 0.906 & 15.00 \\
OPA6 & 09 & 09 & 0 & 100 & 0.00 & 0.822 & 09.00 \\
OPA7 & 09 & 09 & 0 & 100 & 0.00 & 0.762 & 09.00 \\
OPA8 & 14 & 14 & 0 & 100 & 0.00 & 0.895 & 14.00 \\
OPA9 & 17 & 16 & 1 & 99.65 & 0.35 & 0.906 & 16.88 \\
OPA10 & 14 & 14 & 0 & 100 & 0.00 & 0.871 & - \\
Total & 121 & 119 & 2 & - & - & - & 14.00 \\
\hline
\end{tabular}

PIC-Polymorphic Information Content; EMR-Effective Multiplication Ratio

isolates and shared similarity of $27 \%$ and cluster II contained two isolates (SrPLC and Sr KGS). The cluster I had two subclusters viz., subcluster I with sixteen isolates of $S$. rolfsii collected from groundnut and subcluster II with four isolates from black gram, sunflower, tomato and jasmine at $28 \%$ similarity. The results showed genetic variability of $S$. rolfsii with host level.

The binary data from the polymorphism were used for computing the similarity indices. The similarity coefficient values obtained for each pair wise comparison is presented in Table 5. The similarity coefficients ranged from 0.14 to 1.00 . Among the 22 isolates of $\mathrm{S}$. rolfsii, the highest similarity matrix index (0.56) was observed between black gram (Madurai) and tomato (Kinathukadavu). The lowest similarity matrix index (0.14) was observed in the groundnut $S$. rolfsii isolates from Butlagundu and Erisanampatti (Table 5).
The results of genetic diversity between the Sclerotium isolates of groundnut and other hosts were elucidated, indicating the influence of host factor on the genetic makeup of the pathogen. Further, genetic diversity revealed by RAPD primers was not in accordance to the geographical origin of the isolates. Thus, RAPD can be used efficiently to differentiate S. rolfsii groundnut with other hosts. The results of the present study was in accordance with the findings of Almeida et al. (2001), they studied the genetic variability of $S$. rolfsii isolates collected from different hosts in Brazil and found significant genetic variability among isolates using RAPD analysis. During same period, Punja and Sun (2001) studied the genetic diversity of $S$. rolfsii collected from more than ten countries and found high level of variations from the samples collected from different regions. The findings of Perez-Moreno et al. (2002) are also in agreement with the present study and found that genetic polymorphism among the isolates of 


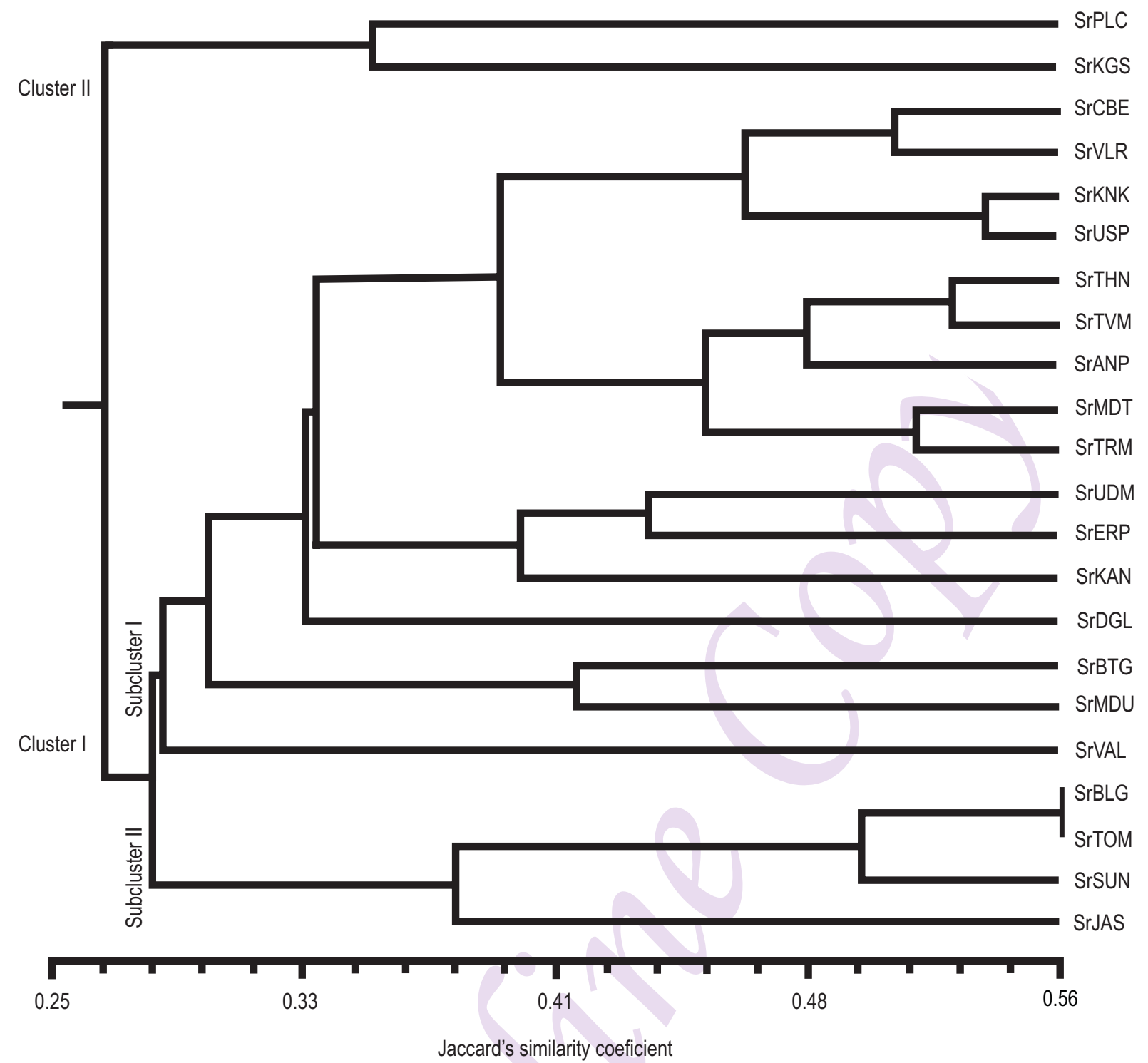

Fig. 3 : RAPD dendrogram showing genetic relationship between twenty two S.rolfsii isolates.

Sclerotium cepivorum collected from Mexico, based on RAPD analysis.

Inter simple sequence repeats (ISSR) is an effective and alternative tool for studying the genetic variability of any living organism due to the presence of microsatellites regions throughout genomes (Raina et al., 2001; Wang, 2002 and Pharmawati et al., 2005). In the present study, ISSR markers were used to investigate the genetic diversity of $S$. rolfsii isolates collected from different geographical regions. All the field samples collected were amplified with ten ISSR primers and produced a total of 123 bands and the amplicon size ranged from 250 - 2000 bp (Fig. 4). Of the ten primers used in the study, most of the primers showed cent per cent polymorphism. However, the primer $(\mathrm{GACA})_{4}$ yielded maximum bands of 17 and all were polymorphic (Table 6 ). Genetic similarity matrix was constructed from binary data of markers using Jaccards algorithm index. The genetic similarity coefficient ranged from 16 to $78 \%$. Maximum similarity of $78 \%$ was observed between SrKGS and SrCBE isolates, and least similarity matrix index of $16 \%$ was observed between SrTVM and SrKGS isolates (Table 7).

A dendrogram resulting from cluster analyses showed two main distinct groups, designated as A and B exhibiting overall genetic relationship among the isolates. Four isolates (SrBLG, SrSUN, SrJAS, SrTOM) were grouped together as group "A" and all other isolates were grouped in "B" at $26 \%$ similarity. Group B was subdivided into two subgroup, I and II. Among the eighteen isolates from group $B$, five isolates were present in subgroup I and the remaining thirteen isolates formed the subgroup II (Fig. 5). The results of the present study with ISSR primer showed high level of polymorphism and genetic diversity, not only at host level 


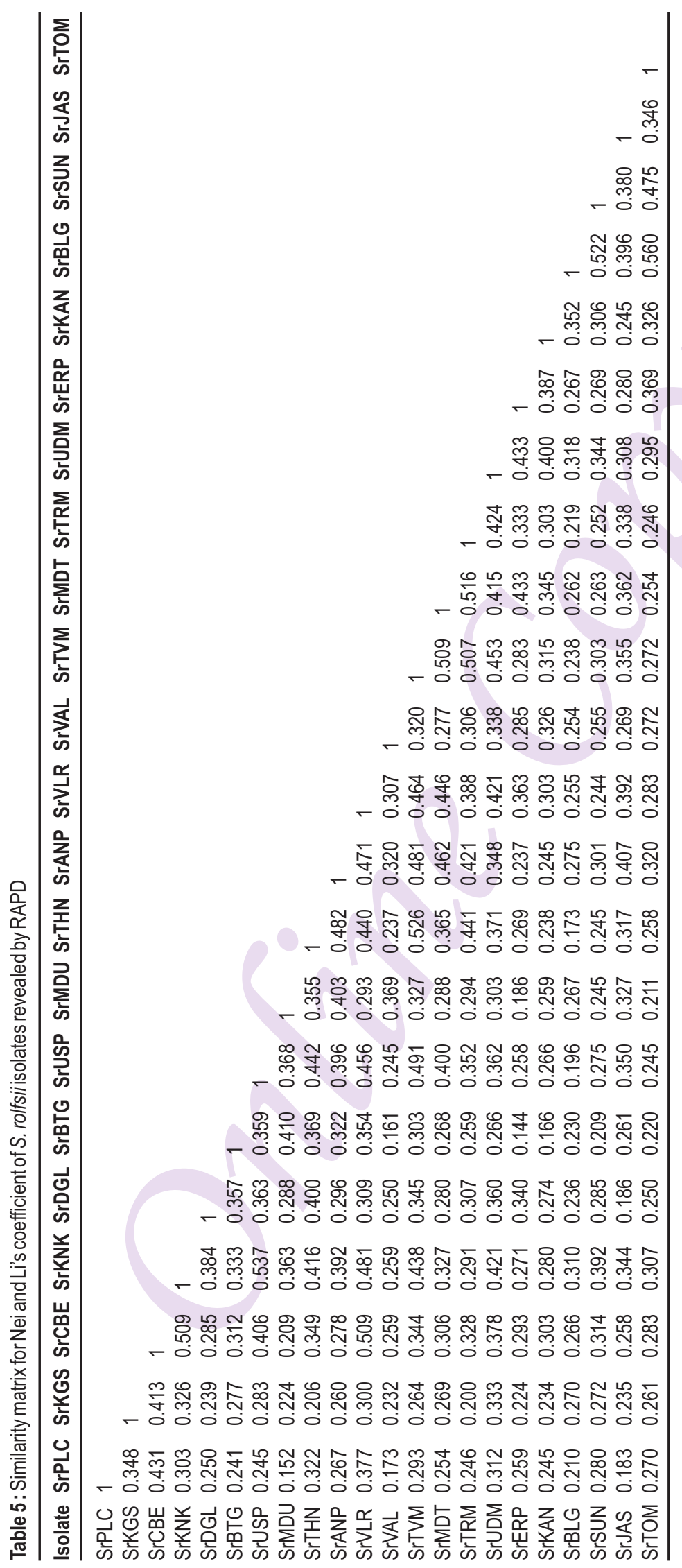


Table 6: Genetic characterization of S. rolfsii isolates revealed by ISSR

\begin{tabular}{|c|c|c|c|c|c|c|c|}
\hline Primer & $\begin{array}{l}\text { Total of } \\
\text { bands }\end{array}$ & $\begin{array}{l}\text { No. of } \\
\text { Polymorphic } \\
\text { bands }\end{array}$ & $\begin{array}{l}\text { No.of } \\
\text { Monomorphic } \\
\text { bands }\end{array}$ & $\begin{array}{l}\text { Per cent } \\
\text { Polymorphic } \\
\text { bands }\end{array}$ & $\begin{array}{l}\text { Per cent } \\
\text { Monomorphic } \\
\text { bands }\end{array}$ & PIC Value & EMR \\
\hline$(C A G)_{5}$ & 11 & 11 & 0 & 100 & 0.00 & 0.884 & 11.00 \\
\hline$(\mathrm{GTG})_{5}$ & 9 & 9 & 0 & 100 & 0.00 & 0.867 & 9.00 \\
\hline$(A G G)_{5}$ & 10 & 10 & 0 & 100 & 0.00 & 0.853 & 10.00 \\
\hline$(\mathrm{GACA})_{4}$ & 17 & 17 & 0 & 100 & 0.00 & 0.902 & 17.00 \\
\hline$(\mathrm{TCC})_{5}$ & 11 & 10 & 1 & 90.91 & 9.09 & 0.857 & 10.82 \\
\hline$(\mathrm{CAC})_{5}$ & 11 & 11 & 0 & 100 & 0.00 & 0.883 & 11.00 \\
\hline$(A G)_{8} T$ & 15 & 15 & 0 & 100 & 0.00 & 0.885 & 15.00 \\
\hline$(A G)_{8} C$ & 12 & 12 & 0 & 100 & 0.00 & 0.894 & 12.00 \\
\hline$(G A)_{8} \mathrm{~T}$ & 8 & 5 & 3 & 62.50 & 37.50 & 0.788 & 07.29 \\
\hline$(\mathrm{TG})_{8} \mathrm{~A}$ & 19 & 19 & 0 & 100 & 0.00 & 0.922 & 19.00 \\
\hline Total & 123 & 119 & 4 & & & 1 & \\
\hline
\end{tabular}

PIC-Polymorphic Information Content; EMR-Effective Multiplication Ratio

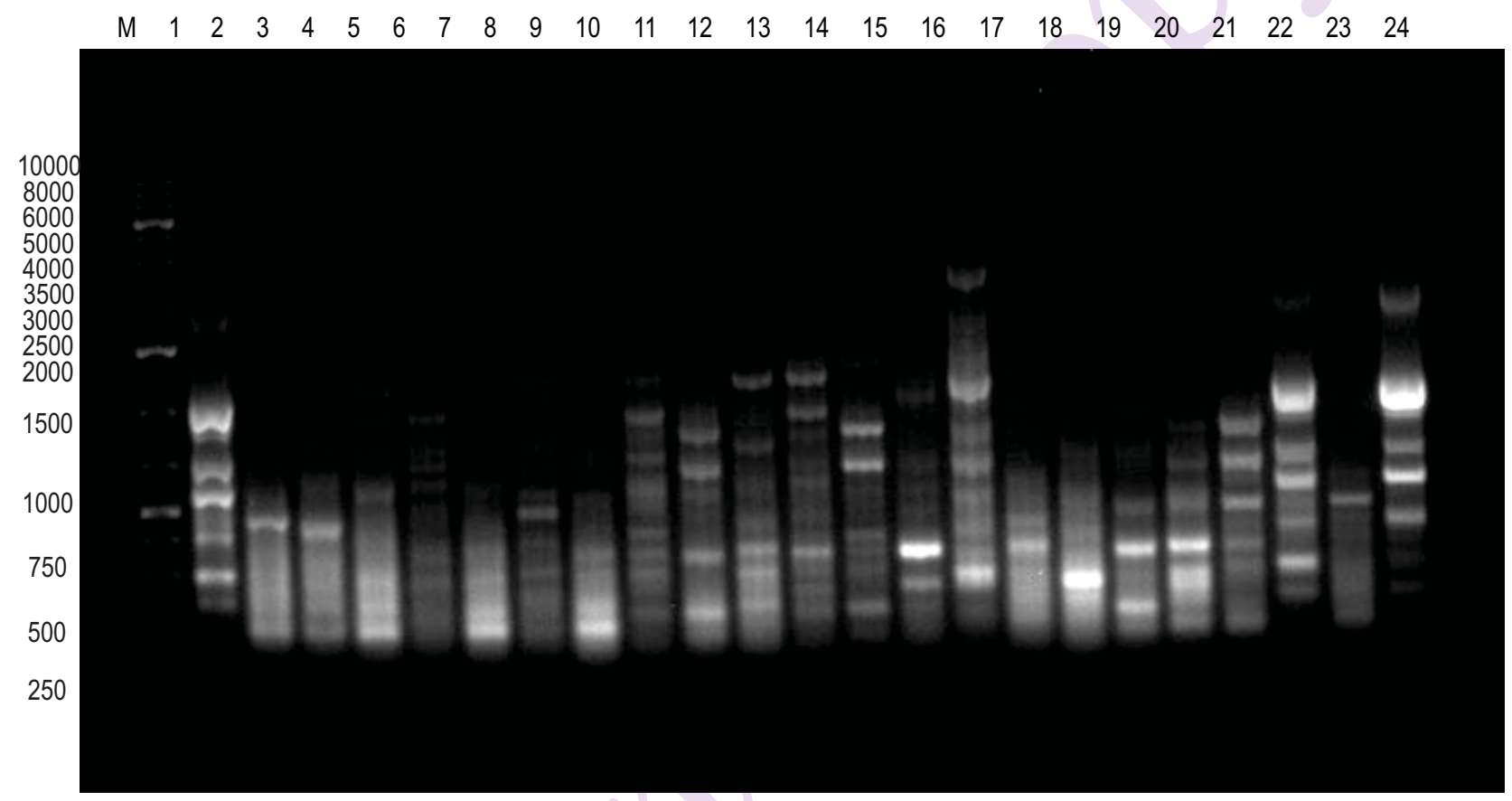

Fig. 4 : DNA banding pro les generated by ISSR-PCR with the primer (GACA)4. Isolates numbers are shown as 1 to 22.23 - Positive control. 24 Negative control. M-1Kb molecular marker

but also at sampling regions. The results of the present study is in agreement with the previous reports of Gupta et al. (1994); Rathour et al. (2004); Misra et al. (2005) where significant level of genetic variations of fungal pathogens were found.

Several workers have reported that the molecular markers are effective for assessing the genetic diversity of fungal pathogens than the conventional methods (Sharma, 2003; Lal and Dutta, 2012; Adhipathi et al., 2013). Hence, the present study focused to assess the genetic variability of $S$. rolfsii using nuclear markers viz., RAPD and ISSR and also validate their efficacy. The parameters including percent polymorphism, polymorphic information content $(\mathrm{PIC})$ and effective multiplication ratio were used to compare the efficiency of marker systems. The total number of bands produced was more in ISSR (123) compared with RAPD (121) (Table 4 and 6). However, the percent polymorphism was almost same in both cases as cent percent polymorphism was recorded in many primers in both markers. The PIC value varied significantly between both markers. The ISSR marker had an average PIC of 0.87 as against 0.86 of 


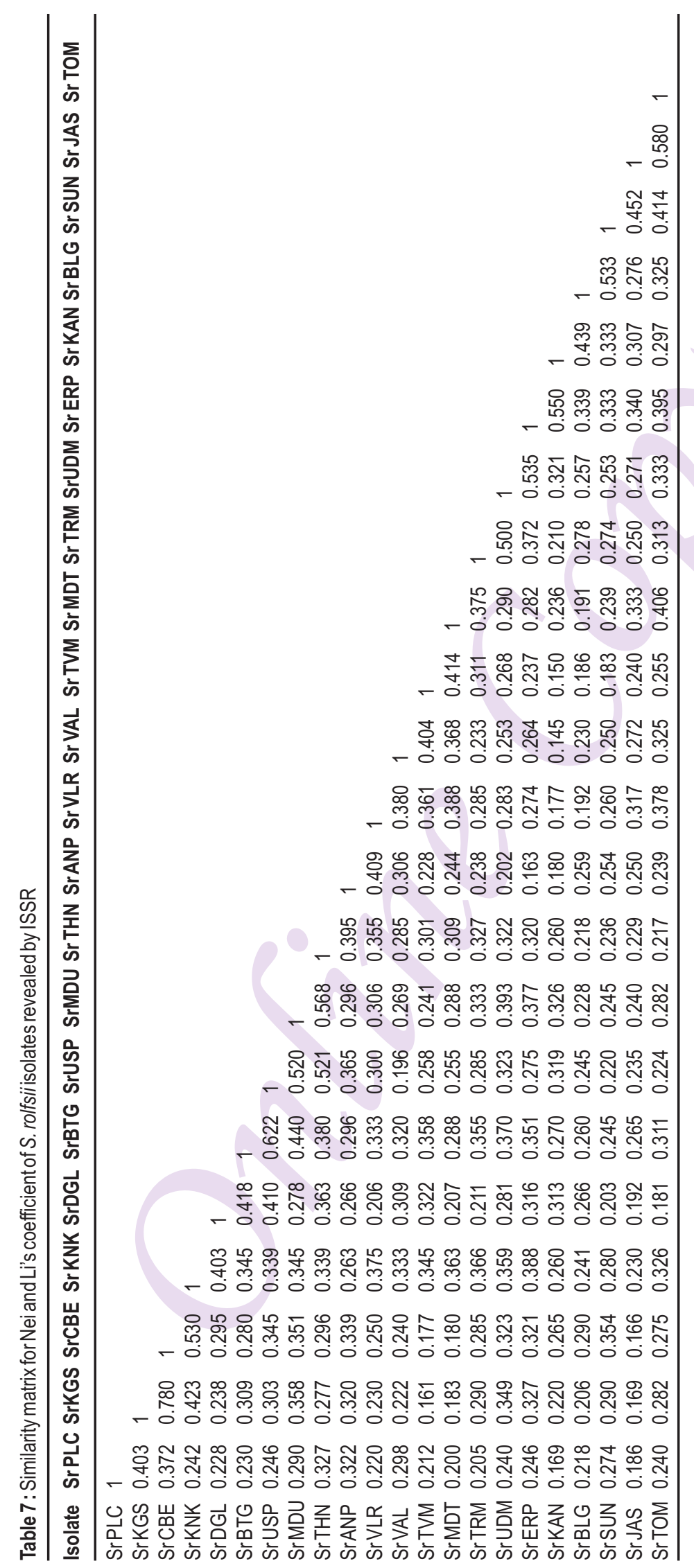




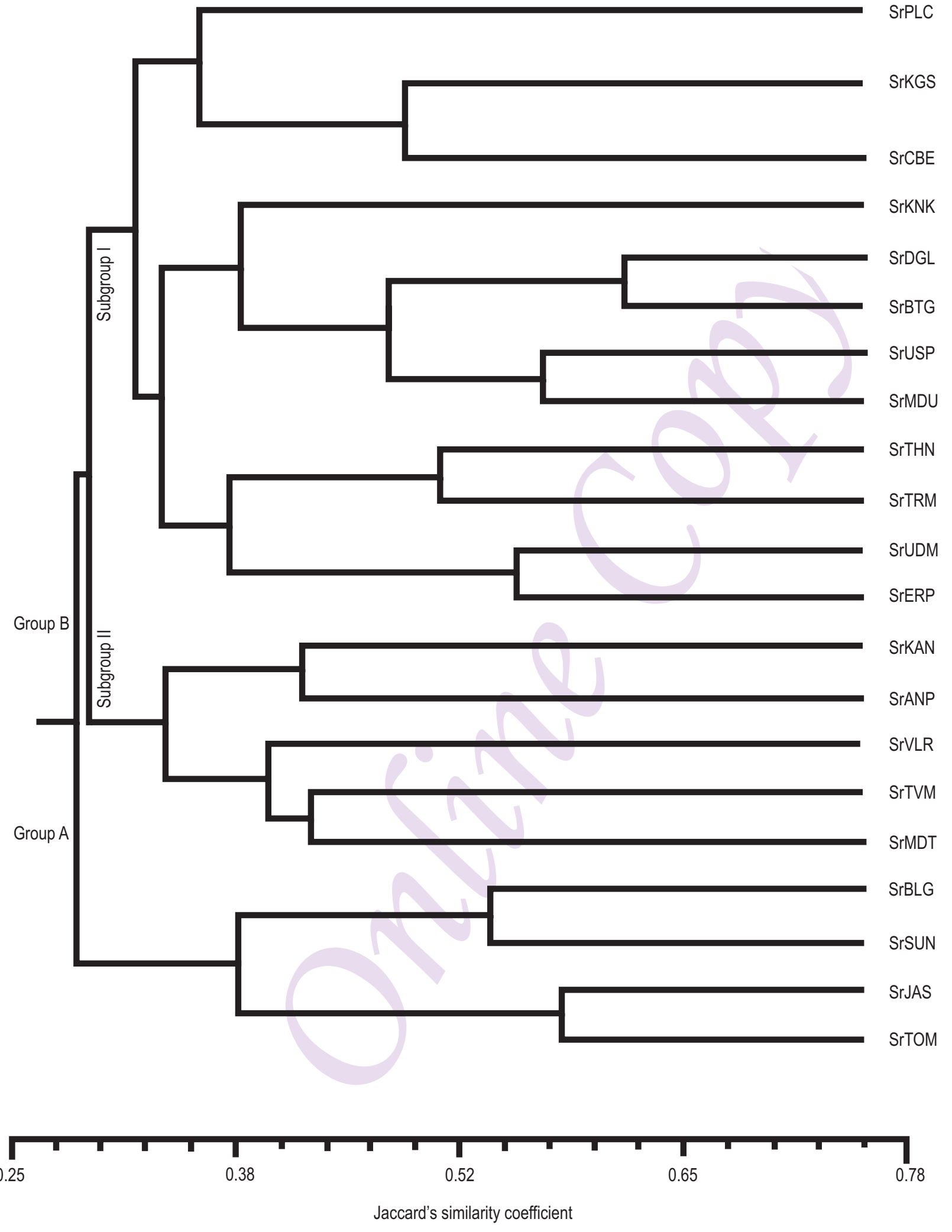

Fig. 5 : ISSR dendrogram showing genetic relationship between twenty two S.rolfsii isolates. 
RAPD, and the effective multiplication ratio was also superior in ISSR (12.21) compared with RAPD (12.00). Thus, considering all parameters studied and also the reproducibility of ISSR markers, it was concluded that ISSR markers are suited well for diversity studies compared to RAPD. The results of the present study is in agreement with the findings of Sonia and Gopalakrishna (2007), who compared the efficacy of ISSR and REMAP for genetic diversity study of Pyricularia oryzae. Among the nuclear markers, the ISSR markers are considered as co-dominant and may help to assess the heterozygosity nature of the samples and also produce high polymorphic information content (PIC). Thus, it was considered as the marker of choice for the genetic diversity of fungal pathogens. The present study also found the superiority of ISSR than RAPD hence, it was demonstrated that the ISSR marker is suitable for genetic diversity of $S$. rolfsii.

The S. rolfsii isolates collected from Udumalpet, K.G. Savadi and Tinidvanam recorded higher per cent disease incidence, and the isolate from Madurai showed lower percent disease incidence. All other isolates showed medium level of per cent disease incidence. Further confirmation with the effective nuclear marker (ISSR) showed not much more variation between the isolates based on percent disease incidence (Virulence). At though, the host wise variation was observed in the present study, the isolates from groundnut formed separate group (Group B) from all other isolates from blackgram, sunflower, jasmine and tomato (Group A), and the variation was also observed within the isolates (Group A \& B) (Fig. 5). The present results showed that there were no correlation between virulence (per cent disease incidence) and genetic diversity of $S$. rolfsii isolates collected from major groundnut growing areas of Tamil Nadu. The genetic variability was observed between the $S$. rolfsii isolates of groundnut and the $S$. rolfsii isolates from blackgram, jasmine, tomato and sunflower. This enunciated that the nature and type of host may influence genetic variation between the isolates.

\section{Acknowledgments}

The authors thank the Department of Plant Pathology, Centre for Plant Protection Studies, Tamil Nadu Agricultural University, Coimbatore, India for providing of chemicals and equipments for this research. The University Grant Commission, India is also acknowledged and thanked for providing the prestigious Maulana Azad National Fellowship (MANF) for the doctoral program to the first author.

\section{References}

Adhipathi, P., S. Nakkeeran and A. Chandrasekaran: Morphological characterization and molecular phylogeny of Colletotrichum capsici causing leaf spot disease of turmeric. The Bioscan, 8, 331337 (2013).

Almeida, A.M.R., R.V. Abdelnoor, E.S. Calvo, D. Tessnman and J.T. Yorinori: Genotypic diversity among Brazilian isolates of Sclerotium rolfsii. J. Phytopathol., 149, 493-502(2001).
Anderson, J.A., G.A. Churchill, J.E. Autrique, S.D. Tanksley and M.E. Sorrells: Optimizing parental selection for genetic linkage maps. Genome, 36, 181-186(1993).

Anonymous: Status paper on oil seeds. Department of Agriculture and Cooperation, Ministry of Agriculture, Government of India (2014).

Asghari, M.A. and C.D. Mayee: Comparative efficacy of management practices on stem and pod rots of groundnut. Ind. Phytopath., 44, 328-332 (1991).

Gaitan, A., A.M. Valderrama, G. Saldarriaga, P. Velez and A. Bustillo: Genetic variability of Beauveria bassiana associated with the coffee berry borer Hypothenemus hampei and other insects. Mycol. Res., 106, 1307-1314 (2002).

Gupta, M., Y.S. Chyi, J.R. Severson and J.L. Owen: Amplification of DNA markers from evolutionarily diverse genomes using single primers of SSRs. Theor. Appl. Genet., 89, 998-1006 (1994).

Gupta, M. and P. Filner: Microsatellites amplify highly polymorphic DNA bands in SPAR of plant DNA. Int. Soc. PI. Molec. Biology, Tucson, USA, 1705 (1991).

Harlton, C.E., C.A. Le'vesque and Z.K. Punja: Genetic diversity in Sclerotium (Athelia) rolfsii and related species. Phytopathol., 85, 1269-1281 (1995).

Hossain, I.: Biocontrol of Fusarium oxysporum and Sclerotium rolfsii infection in lentil, chickpea and mungbean. BAU Research Programme,11,61-65(2000).

Jaccard, P.: Nouvelles recherché sur la distribution florale. Bull. Soc. V. Sci. Nat., 44, 223-270 (1908).

Johnson, W.C., B.G. Mullinix and M.A. Boudreau: Peanut response to naturally-derived herbicides used in organic crop production. Pea. Sci.,14, 35-39 (2008).

Kokub, D., F. Azam, A. Hassan, M. Ansar, M.J. Asad and A. Khanum: Comparative growth, morphological and molecular characterization of indigenous Sclerotium rolfsii strains isolated from different locations of Pakistan. Pak. J. Bot., 39,1849-1866 (2007).

Kokalis-Burelle, N., P.A. Backman, R.R. Kabana and L.D. Ploper: Potential for biological control of early leafspot of peanut using Bacillus cereus and chitin as foliar amendments. Biolog. Cont., 2, 321-328 (1992).

Kumar, P., V.K. Gupta, A.K. Misra and D.R. Modi: Molecular characterization of Fusarium moniliforme var.subglutinans isolates. J. Environ. Biol., 35, 211-216 (2014).

Lal, N. and J. Dutta: Progress and perspectives in characterization of genetic diversity in plant pathogenic Fusarium. Plant Arch., 12, 557-568 (2012).

Mallaiah, B. and M. Muthamilan: Genetic variation amongst the isolates of Fusarium incarnatum(Desm.) Sacc., incitant of wilt in crossandra. Inter. J. Trop. Agric., 33, 1679-1685 (2015).

Misra, D., U.D. Singh, A.B. Dash, J.N. Reddy and R. Sridhar: Analysis of Pyricularia grisea populations from three different blast epidemics. Inter. Rice Res. Newslett., 31,22-23 (2005).

Moulin, M.M., R. Rodrigues, L.S.A. Gonçalves, C.P. Sudré and M.G. Pereira: A comparison of RAPD and ISSR markers reveals genetic diversity among sweet potato landraces (Ipomoea batatas (L.) Lam.). Acta Scient., 34, 139-147 (2012).

Pharmawati, M., G. Yan and P.M. Finnegan: Molecular variation and fingerprinting of leucadendron cultivars (Proteaceae) by ISSR markers. Ann. Bot., 95, 1163-1170 (2005).

Perez-Moreno, L., V.O. Portugal, G.J. Vandemark, O.M. la Vega, J.P.M. Soriano, G.V. Marrufo and J.L. Reyna: Genetic relationships 
among isolates of Sclerotium cepivorum Berk. based on RAPD analysis. Rev. Mexicana de Fitopatol., 20, 187-192 (2002).

Powell, W., M. Morgante, C. Andre, M. Hanafey, J. Vogel, S. Tingey and A. Rafalski: The comparison of RFLP, RAPD, AFLP and SSR markers for germplasm analysis. Mol. Breed., 2, 225-238 (1996).

Prasad, S.D., S.T. Basha and N.P.G.E. Reddy: Molecular variability among the isolates of Sclerotium rolfsii causing stem rot of groundnut by RAPD, ITS-PCR and RFLP. Eur. Asia. J. Bio. Sci., 4, 80-87 (2010).

Punja, Z.K.: The biology, ecology and control of Sclerotium rolfsii. Annual Rev. Phytopathol., 23, 97-127 (1985).

Punja, Z.K. and L.J. Sun: Genetic diversity among mycelia compatibility groups of Sclerotium rolfsii (telemorph: Athelia rolfsii) and $S$. delphenii. Mycol. Res., 105, 537-546 (2001).

Raina, S.N., V. Rani, T. Kojima, Y. Ogihara, K.P. Singh and R.M. Devarumath: RAPD and ISSR fingerprints as useful genetic markers for analysis of genetic diversity, varietal identification, and phylogenetic relationships in peanut (Arachis hypogaea) cultivars and wild species. Genome, $44,763-772$ (2001).

Rangasawami, G.: Diseases of crop plants in India. Prentice Hall of India Pvt. Ltd. New Delhi (1996).

Ratanacherdchai, K., H.K. Wang, F.C. Lin and K. Soytong: RAPD analysis of Colletotrichum species causing chilli anthracnose disease in Thailand. J. Agric. Technol., 3, 211-219 (2007) .

Rathour, R., B.M. Singh, T.R. Sharma and R.S. Chauhan: Population structure of Magnaporthe grisea from North-Western Himalayas and its implications for blast resistance breeding of rice.
Phytopathology, 152, 304-312 (2004).

Ricker, A. J. and R.S. Ricker: Introduction to research on plant diseases. John Swift Co., St. Louis, Chicago (1936).

Rodriguez, K.R., P.A. Backman and J.C. Williams: Determination of yield losses to Sclerotium rolfsii in peanut fields. Plant Dis. Rep., 59, 855-858 (1975).

Rohlf, F.J.: NTSYS-pc: Numerical taxonomy and multivariate analysis system, v. 2.0. Exeter Software. Setauket, New York (1993).

Sharma, T.R.: Molecular diagnosis and application of DNA markers in the management of fungal and bacterial plant diseases. Ind. J. Biotechnol., 2, 99-109 (2003).

Sonia, C. and T. Gopalakrishna: Comparative assessment of REMAP and ISSR marker assays for genetic polymorphism studies in Magnaporthe grisea. Curr. Sci., 93, 688-692 (2007).

Thilagavathi, R., S. Nakkeeran, T. Raguchander and R. Samiyappan: Morphological and genomic variability among Sclerotium rolfsii populations. The Bioscan, 8, 1425-1430 (2013).

Wang, J.B.: ISSR markers and their applications in plant genetics. $Y_{i}$ Chuan, 24, 613-616 (2002).

Weising, K., F. Weigand, A. Driesel, G. Kahl, H. Zischer and J.T. Epplen: Polymorphic sample GATA/GACA repeats in plant genomes. Nucl. Acid. Res., 17, 10128 (1989).

White, T.J., T. Bruns, S. Lee and J. Taylor: Amplification and direct sequencing of fungal ribosomal RNA genes for phytogenetics in PCR protocols. Academic Press, London (1990).

Zolan, M.E. and P.J. Pukkila: Inheritance of DNA methylation in Coprinus cinereus. Mol. Cell Bio., 6, 195-200 (1996) 